\title{
Rapid diagnosis of red sea bream iridovirus infection using the polymerase chain reaction
}

\author{
Syunichirou Oshima ${ }^{1}$, Jun-ichiro Hata ${ }^{1}$, Noritaka Hirasawa ${ }^{2}$, Taro Ohtaka ${ }^{2}$, \\ Ikuo Hirono ${ }^{3}$, Takashi Aoki ${ }^{3}$, Shinya Yamashita ${ }^{1, *}$ \\ ${ }^{1}$ Central Research Laboratory, Nippon Suisan Kaisha Ltd, 559-6, Kitanomachi, Hachioji, Tokyo 192, Japan \\ ${ }^{2}$ Ohita Marine Center, Nippon Suisan Kaisha Ltd, Tsurumicho, Minamiamabegun, Ohita 508-8, Japan \\ ${ }^{3}$ Department of Aquatic Biosciences, Tokyo University of Fisheries, Konan, Minato, Tokyo 108, Japan
}

\begin{abstract}
A simple and sensitive polymerase chain reaction (PCR) based assay is described for detection of the red sea bream iridovirus (RSIV) in infected fish. The assay involves amplification of a portion of the ribonucleotide reductase small subunit (RNRS) gene of the virus from DNA isolated from the spleen. The system was tested on red sea bream following an experimental infection. In our infection model, disease signs first became apparent 5 to $6 \mathrm{~d}$ post-infection, and mortality commenced at Day 6 and reached $90 \%$ by Day 9. No amplified product was detected from fish at 1 or 2 d postinfection, but 3 of 5 fish tested positive at Day 3, and all fish tested positive at Days 5 and 8 . Thus, infection could be detected prior to the appearance of overt symptoms. This PCR method should be of considerable value for aquaculture to detect RSIV infection
\end{abstract}

KEY WORDS: Red sea bream $\cdot \mathrm{PCR} \cdot \mathrm{RSIV} \cdot$ Iridovirus $\cdot$ Infection

\section{INTRODUCTION}

The red sea bream irido virus (RSIV) was first isolated from the cultured red sea bream Pagrus major in 1992 (Inouye et al. 1992) and has since been found to infect several other important cultured fish, resulting in significant economic losses (Nakajima \& Sorimachi 1994, Nakajima et al. 1995). Diseased fish are lethargic and have severe anemia, petechia of the gills, and hypertrophic spleens. Histopathologically, fish infected with RSIV display enlarged cells in the spleen, kidney, liver and gill that stain strongly with Giemsa solution. Electron microscopic observations identify RSIV as an icosahedral cytoplasmic deoxyribovirus of the Indoviridae (Inouye et al. 1992). Cell culture and immunological assays are the established methods for the diagnosis of RSIV (Nakajima \& Sorimachi 1995, Nakajima et al. 1995). Recently, however, several molecular biological techniques, such as nucleic acid hybridiza-

\footnotetext{
"Addressee for correspondence.

E-mail: kye00332@niftyserve.or.jp

tion (Southern 1975) and the polymerase chain reaction (PCR) (Saiki et al. 1988), have shown promise for providing more convenient viral assays (Saiki et al. 1988). The feasibility of using PCR to detect other viral infections of fish has recently been demonstrated (Arakawa et al. 1990, Nishizawa et al. 1994). Accordingly, we sought to develop a rapid and sensitive PCRbased assay that can detect RSIV infection at a phase sufficiently early to be an aid in the management of fish cultivation.

Recently, we described a method for isolating a DNA segment of a virus for which no protein or DNA. sequence information is available. This method is based on the widespread presence and strong conservation of the RNRS gene among DNA viruses (Oshima et al. 1996). We reported the isolation from infected fish of a 738 base pair (bp) segment of the RSIV ribonucleotide reductase small subunit gene (RNRS) (Oshima et al 1996). We also isolated and sequenced the endogenous RNRS gene from the red sea bream host fish (Oshima et al. 1996). The host sequence was highly homologous to that of the RSIV fragment, but had sufficient nucleotide differences to enable design of PCR primers that 
would specifically amplify the viral segment. This indicated that our procedure for isolating a DNA segment from a previously uncharacterized virus could lead directly to the development of a PCR-based assay for that virus. In this study, we assess the applicability of several specific PCR primers for the rapid and early diagnosis of RSIV infection.

\section{MATERIALS AND METHODS}

Virus. Red sea bream that had died after showing signs of RSIV infection were obtained from the southwestern region of Japan. As is typical for the disease, these fish had enlarged spleen cells that stained strongly with Giemsa solution (Inouye et al. 1992). To prepare the inoculum for the experimental infection, the spleens of diseased fish were homogenized in 10 volumes of phosphate-buffered saline (PBS), centrifuged at $3000 \mathrm{rpm}$ for $10 \mathrm{~min}$, and the supernatant fraction passed through a $0.45 \mathrm{~mm}$ filter and stored at $-80^{\circ} \mathrm{C}$ until used. Virus titers of the inoculum and of extracts used for PCR were determined by counting the cytopathic effect (CPE) using the BF2 cell line (Nakajima \& Sorimachi 1994).

Isolation of DNA. For DNA isolation, samples of about $10 \mathrm{mg}$ of spleen or $10 \mu \mathrm{l}$ of whole blood from the red sea bream were homogenized with a plastic homogenizer in $500 \mu$ l of TE buffer (10 mM Tris-HCl pH 7.5, $1 \mathrm{mM}$ EDTA) containing $1 \%$ sodium dodecyl sulphate (SDS). After centrifugation at $3000 \mathrm{rpm}$ for $10 \mathrm{~min}$, supernatant fractions were extracted twice with phenol-chloroform; the DNA was precipitated with ethanol, and redissolved in $100 \mu \mathrm{l}$ of TE buffer and stored at $-80^{\circ} \mathrm{C}$ until used. The amount of extract used for each PCR reaction was $1 \mu$, i.e. the amount obtained from $0.1 \mathrm{mg}$ of tissue. Plasmid pRS1, which contains the segment of RSIV obtained by PCR amplification, has previously been described (Oshima et al. 1996).

RNRS gene detection using PCR. Five 20-mer deoxyoligonucleotide primers for PCR amplification of RSIV RNRS gene fragments were designed based on the sequence data reported previously (Oshima et al. 1996) (see also accession number D86858). These comprise 2 sense primers (V1 and V2) and 3 antisense primers (V3, V4 and V5) as follows: V1, 5'-CACGTGTTGGCTTTCTTCGC; V2, 5'-GCATGTATGCTGTTTAGACA; V3, 5'-GCATGAGAGAACGCTCCTTC; V4, 5' -AGACAGGCAAAGTCACAGTG; V5, 5'-GAGCATCAAGCAGGCGATCT. Except for the change in template and primer pairs, the PCR reaction mixture used was as described previously (Yamada et al. 1993). Amplification conditions were 30 cycles of denaturation at $94^{\circ} \mathrm{C}$ for $30 \mathrm{~s}$, annealing at $58^{\circ} \mathrm{C}$ for $60 \mathrm{~s}$ and elongation at $72^{\circ} \mathrm{C}$ for $90 \mathrm{~s}$, followed by a final exten- sion at $72^{\circ} \mathrm{C}$ for $10 \mathrm{~min}$. The amplified samples were electrophoresed on a $2 \%$ agarose gel and visualized by staining with ethidium bromide at a concentration of $1 \mu \mathrm{g} \mathrm{ml}^{-1}$.

Experimental infection of RSIV. Red sea bream juveniles (mean body weight $10 \mathrm{~g}$ ) were bred and reared in the aquarium facility of the Ohita Marine Research Center of Nippon Suisan Kaisha Ltd. One hundred fish were inoculated intraperitoneally with $0.1 \mathrm{ml}$ virus suspension containing $10^{6}$ plaque forming units (pfu) $\mathrm{ml}^{-1}$ of RSIV, and held in a $50 \mathrm{l}$ tank supplied with running water regulated at $25^{\circ} \mathrm{C}$. For controls, 100 uninfected fish were similarly housed in a separate tank. Five live fish from each tank were euthanized on Days 1, 2, 3, 5 and 8 after RSIV inoculation. The spleen and whole blood of each fish were immediately removed and stored at $-80^{\circ} \mathrm{C}$. In order to determine the survival ratio, parallel groups of 100 infected and uninfected fish were housed in separate tanks

\section{RESULTS AND DISCUSSION}

\section{Selection of the PCR primers}

Several candidate primer pairs whose sequences were specific for the RNRS gene of RSIV were synthesized. The nucleotide sequences of the primers are given in 'Materials and methods', and their approximate locations and the expected product sizes are shown in Fig. 1. The primer pairs were tested for their ability to specifically and efficiently amplify the corresponding RSIV RNRS gene fragments, using as template DNA isolated from the spleen of fish killed by the virus. Following the PCR amplifications, the reaction products were analyzed by agarose gel electrophoresis. As shown in Fig. 2, each of the primer pairs tested, V1/V5, V1/V4, V1/V3, and V2/V5 (Fig. 1), generated a single predominant product having the expected size. The identities of these products were confirmed by subcloning and sequencing (data not shown). The V2/V5 primer pair, which produces a product of about $187 \mathrm{bp}$, was selected for further studies.

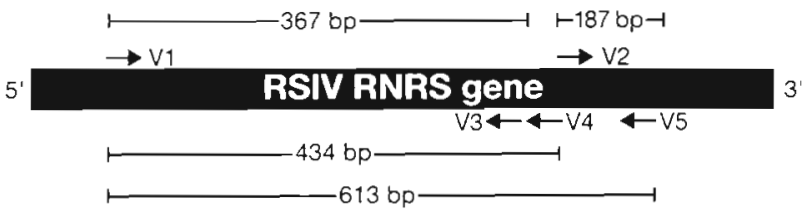

Fig. 1. Schematic illustration of the physical map of the RSIV RNRS gene. Positions of the 2 sense primers (V1 and V2), and 3 antisense primers (V3, V4 and V5) for PCR amplification are shown, along with the expected sizes of the PCR amplification products 

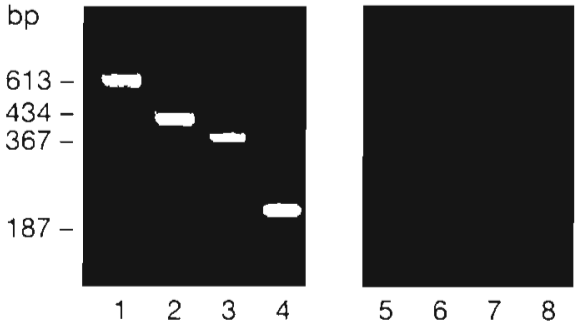

Fig. 2. Amplification of RNRS gene using specific primer pairs. DNA isolated from the spleen of diseased fish (lanes 1-4) and healthy fish (lanes 5-8) was amplified using the following primer pairs: lanes 1,5 : V1/V5; lanes 2,6 : V1/V4; lanes 3,7 : $\mathrm{V} 1 / \mathrm{V} 3$; lanes 4, 8: V2/V5. The aliquot of DNA in each reaction from the diseased spleen was isolated from an amount of extract that contained approximately $10^{4}$ pfu. Reaction products were resolved on an agarose gel and stained with ethidium bromide. DNA fragment sizes were estimated using molecular size markers (Boehringer; not shown)

\section{Sensitivity of the PCR}

To determine the sensitivity of the PCR amplification, different quantities of plasmid $\mathrm{pRS} 1$, which carries a fragment of the RSIV RNRS gene (Nishizawa et al. 1994), were used as template. Amounts used ranged from $0.1 \mathrm{fg}$ to $1 \mathrm{ng}$, in 10 -fold increments. As shown in Fig. 3, the expected 187 bp DNA fragment was detected from samples containing as little as $10 \mathrm{fg}$ of $\mathrm{pRS} 1$ DNA, which corresponds to approximately 2000 molecules of the $3800 \mathrm{bp}$ plasmid. This is in good correspondence with the sensitivity of assays of DNA extracted from infected spleen based on the virus titer of the extract solution (Fig. 3, lanes 11-13), and is similar to that previously reported for viral detection systems using PCR (Cassinotti et al. 1993, Nishizawa et al. 1994).

\section{Experimental RSIV infection}

The stage of RSIV infection at which the virus can first be detected using PCR amplification was evaluated in an experimental RSIV infection. One hundred red sea bream juveniles (mean body weight $10 \mathrm{~g}$ ) were inoculated intraperitoneally with $10^{5} \mathrm{pfu}$, and their survival was monitored daily for $14 \mathrm{~d}$ (Fig. 4A). Symptoms of disease were first apparent on Day 5 post-infection, and mortality began on Day 6, reaching $98 \%$ by Day 12 . All 100 fish in a control group survived the entire period. Five live fish were collected from the infected group on Days 1, 2, 3, 5 and 8 after infection, and their spleen and blood samples used to prepare DNA. As shown in Fig. 4B, there were no signals at 1 and $2 \mathrm{~d}$ postinfection, but 3 of the 5 fish yielded a positive signal at 3 d post-infection, and all 5 were positive on Days 5 and 8. Thus, our PCR-based RSIV assay could detect the RSIV infection prior to the onset of overt symptoms of the disease.

In an attempt to make the system still more convenient, we next examined whether DNA isolated from blood could be used. However, none of the samples yielded positive signals, including those isolated from fish 5 and $8 \mathrm{~d}$ post-infection. This result suggests that the level of RSIV in the blood is quite low compared to that in the spleen.

In conclusion, we have described a simple, new, PCR-based assay for the detection of RSIV infection in
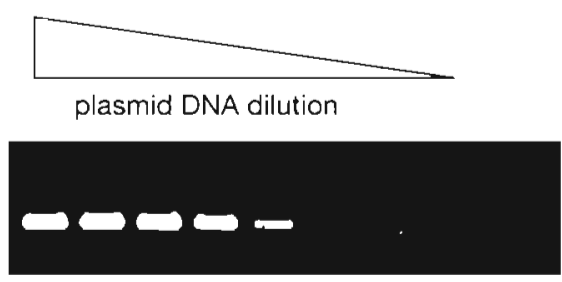

1

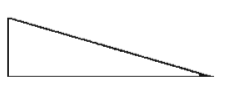

viral DNA dilution

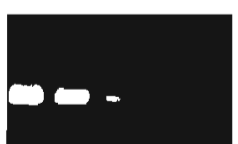

$10 \quad 11 \quad 12 \quad 13 \quad 14$

Fig. 3. Sensitivity of PCR detection of the RSIV RNRS gene Ethidium bromide-stained agarose gel showing the PCR products generated with the V2/V5 primer pair from serial dilutions of either pRS1 DNA (lanes 1-10) or of extract of an infected spleen (lanes 10-14). pRS1 DNA and virus fraction as indicated titers. Lane 1: $1 \mathrm{ng}$ of pRS1 DNA; lane 2: $100 \mathrm{pg}$; lane 3: $10 \mathrm{pg}$; lane 4:1 pg; lane 5: $100 \mathrm{fg}$; lane 6: $10 \mathrm{fg}$; lane 7 $1 \mathrm{fg}$; lane 8: $0.1 \mathrm{fg}$; lane 9: no DNA (negative control); lane 10 DNA from spleen extract that contained $10^{4}$ pfu; lane 11

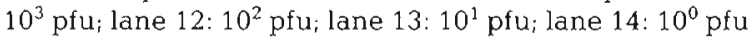
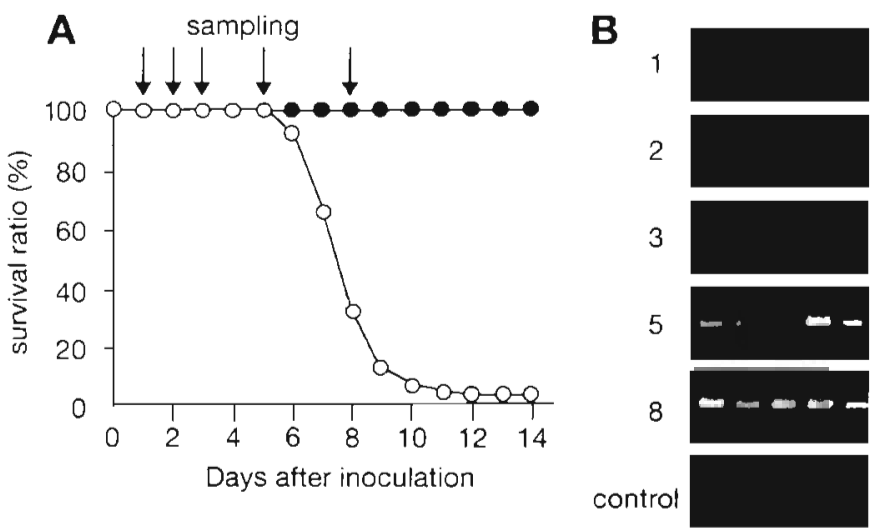

Fig. 4. Detection of the RSIV RNRS gene at various times after infection using PCR amplification. (A) Survival rate of 100 red sea bream challenged with RSIV. The graph shows the percentage of fish surviving as measured in daily intervals during $14 \mathrm{~d}$ post-infection (O) and the survival of control fish (@). (B) PCR amplification of the RSIV RNRS gene fragment from infected fish. PCR was performed using the V2/V 5 primer pair on DNA isolated from the spleen of 5 fish harvested at each of the post-infection days indicated, or from uninfected fish control fish at $8 \mathrm{~d}$. The PCR products were resolved on an agarose gel and stained with ethidium bromide 
fish. The sensitivity and speed of the assay permit infections to be discovered at an early stage: the sensitivity is sufficient to detect the virus prior to the appearance of disease symptoms, and it is possible to proceed from tissue sampling to a final result in a single day. In addition, we note that the procedures described here and in our previous publication (Oshima et al. 1996) should be generally applicable for the rapid development of a PCR-based assay for DNA virus, even if prior protein or DNA sequence information for the virus is not available. Our previous paper described how it is possible to amplify a segment of the RNRS gene from an uncharacterized DNA virus, and here we demonstrate that differences between the viral and host DNA sequences can be exploited for a viral-specific assay. These attributes should make this new PCR-based assay a valuable resource for monitoring the health of cultured fish.

Acknowledgement. We are grateful to Dr Michael Brenner (National Institute of Health, NINDS) for a critical reading of this manuscript.

\section{LITERATURE CITED}

Arakawa CK, Deering RE, Higman KH, Oshima $\mathrm{KH}, \mathrm{O}^{\prime}$ Hara PJ, Winton JR (1990) Polymerase chain reaction (PCR) amplification of a nucleoprotein gene sequence of infectious hematopoietic necrosis virus. Dis Aquat Org 8: $165-170$

Editorial responsibility: Jo-Ann Leong,

Corvallis, Oregon, USA
Cassinotti P, Weitz M, Siegl G (1993) Human Parvovirus B19 infections: routine diagnosis by a new nested polymerase chain reaction assay. J Med Virol 40:228-234

Inouye $K$, Yamano K, Maeno $Y$, Nakajima $K$, Matsuoka M, Wada Y, Sorimachi $M$ (1992) Iridovirus infection of cultured red sea bream, Pagrus major. Fish Pathol 27:19-27

Nakajima $K$, Maeno Y, Fukudome $M$, Fukuda $Y$, Tanaka S, Matsuoka S, Sorimachi M (1995) Immunofluorescence test for rapid diagnosis of red sea bream iridovirus infection using monoclonal antibody. Fish Pathol 30:115-119

Nakajima K. Sorimachi M (1994) Biological and physicochemical properties of the iridovirus isolated from cultured red sea bream, Pagrus major. Fish Pathol 29:29-33

Nakajima K, Sorimachi M (1995) Production of monoclonal antibodies against red sea bream iridovirus. Fish Pathol 30:47-52

Nishizawa T, Mori K, Nakai T, Furusawa I, Muroga K (1994) Polymerase chain reaction (PCR) amplification of RNA of striped jack nervous necrosis virus (SJNNV). Dis Aquat Org 18:103-107

Oshima S, Hata JI, Segawa C, Hirasawa N, Yamashita S (1996) A method for direct DNA amplification of uncharacterized DNA viruses and for development of a viral polymerase chain reaction assay: application to the red sea bream iridovirus. Anal Biochem 242:15-19

Saiki RK, Gelfand DH, Stoffel S, Scharf SJ, Higuchi R, Horn GT, Mullis KB, Erlich HA (1988) Primer-directed enzymatic amplification of DNA with a thermostable DNA polymerase. Science 239:487-491

Southern EM (1975) Detection of specific sequence among DNA fragments separated by gel electrophoresis. J Mol Biol 98:503-517

Yamada S, Hata JI, Yamashita S (1993) Molecular cloning of fish Pit-1 cDNA and its functional binding to promoter of gene expressed in the pituitary. J Biol Chem 268: $24361-24366$

Submitted: June 10, 1997; Accepted: September 24, 1997

Proofs received from author(s): February 16, 1998 